\title{
RESEARCH NOTE \\ Scientific productivity and collaboration in viticulture and enology in Latin American countries
}

\author{
José Luis Aleixandre', Edmundo Bordeu², José Luis Aleixandre-Tudó', \\ Máxima Bolaños ${ }^{3}$ and Rafael Aleixandre-Benavent ${ }^{3,4}$ \\ 'Departamento de Tecnología de Alimentos, Universidad Politécnica de Valencia, Camino de Vera, s/n, \\ 46022. Valencia, Spain. \\ ${ }^{2}$ Facultad de Agronomía e Ingeniería Forestal. Pontificia Universidad Católica de Chile. Vicuña Mackenna \\ 4860. Santiago, Chile. \\ ${ }^{3}$ Unidad de Información e Investigación Social y Sanitaria. Universidad de Valencia, Plaza Cisneros, 4, \\ 46003. Valencia, Spain. \\ ${ }^{4}$ Instituto de Historia de la Medicina y de la Ciencia López Piñero. Consejo Superior de Investigaciones \\ Científicas, Plaza Cisneros, 4, 46003. Valencia, Spain.
}

\begin{abstract}
J.L. Aleixandre, E. Bordeu, J.L. Aleixandre-Tudó, M. Bolaños, and R. AleixandreBenavent. 2013. Scientific productivity and collaboration in viticulture and enology in Latin American countries. Cien. Inv. Agr. 40(2): 429-443. The aim of this study was to analyze the scientific activity of Latin American researchers in viticulture and oenology through bibliometric analyses of articles included in the Science Citation Index Expanded database for the period of 2006 to 2010. A total of 917 research articles were published in 364 domestic and international journals. We highlight the important growth in the number of research papers published during the period, especially in Brazil, Argentina and Chile, as well as an increasing number of international collaborations, mainly with non-American grape- and-wine producing countries. A social network analysis of collaborations between institutions and countries was also performed. The combined analysis of productivity, collaboration and scientific impact provides a global and integrated vision of the research conducted in this area in Latin America.
\end{abstract}

Key words: Impact factor, Latin American countries, network analysis, scientific collaboration, scientific productivity, viticulture and enology.

\section{Introduction}

Four countries, Argentina, Chile, Uruguay and Brazil, are the major producers of wine and have the largest areas under grape cultivation in Latin America. The wine regions are located in

Received July 12, 2012. Accepted June 1, 2013.

Corresponding author: jaleixan@tal.upv.es temperate climates on the slopes of mountains and valleys. Good soil and climatic conditions have made it possible for nearly 3,000 growers to cultivate over 500,000 hectares of vineyards in the region.

There are nearly 700 wineries that utilize approximately $70 \%$ of the total production of grapes in Latin America (Aleixandre and Crespo, 2005). 
While production has traditionally been dominated by red wines, there is now a tendency towards a balance between white and red wines and an increasing amount of distillates and table grapes. There is also a growing interest in the treatment of waste water produced by the expanding wine industry (Gonzalez et al. 2003; Oliver et al. 2006).

Some countries in Latin America hold much prestige within the group of New World winemaking countries. In particular, Argentina, Chile, Brazil and Uruguay produce $90 \%$ of the wines in the area, a total production of approximately 30 million hectoliters, and are the 5th, 10th, 15th and 20th highest ranked producers in the world, respectively. They export about one quarter of the wine produced, and international sales are increasing. Efforts to geographically characterize the region's wine and spirits and to develop and adapt foreign varieties are increasing as evidenced by the numerous papers published by GonzalezNeves et al. (2010) Lucena et al.(2010), Fanzone et al. (2012), and Granato et al. (2011).

The Latin American wine industry is backed by organizations, such as institutes and departments of viticulture and enology in public and private universities, that train technicians in the management of vineyards and wineries. Thus, the current relevance of the Latin American wine industry justifies an analysis of the scientific and research activities in this part of the world.

Papers published in scientific journals are one of the measurable outcomes of research activity and may be analyzed using qualitative and quantitative methods. The qualitative method of "peer review", which is based on expert opinion, is an indispensable basic condition that is imposed by editors before research will be published in prestigious scientific journals. The quantitative determination is based on a series of measures or indicators that are derived from statistical analysis of published scientific literature and included in bibliographic databases (White and McCain, 1989). These indicators reflect the scientific activity of researchers and their institutions by determining which papers they have published, the characteristics of the literature and the number of collaborative relationships represented by the papers. Authors confer accreditation to colleagues' publications by citing them, so citation counts reflect the impact that published papers have had on subsequent publications and their authors (Aleixandre-Benavent et al., 2007).

Scientific collaboration facilitates the flow of information among researchers and also allows for cost-sharing and improved efficiency in research (Kretschmer, 1994; Mewman, 2004). One way to determine the level of established cooperation is to count the number of co-authorships in an area of scientific research. The co-authorship relationship occurs when two or more authors or institutions contribute to the same scientific paper (Newman, 2004). Using social network analysis, these interpersonal and inter-institutional collaborations can be represented by graphs that quantify how many members make up a network, the intensity of their relationships and which members are the most relevant (Newman, 2004; González-Alcaide et al. 2008a). Researchers with the largest number of collaborative publications are at the "research front' of that field (González-Alcaide et al., 2008b).

The aim of this study was to analyze the scientific activity of Latin American researchers in viticulture and enology through bibliographic analyses of articles in the Science Citation Index Expanded (SCI-E) database for the period of 2006 to 2010. The length of this time period allows us to obtain comprehensive information with which to establish trends in research in the field. Moreover, the joint analysis of productivity, collaboration and scientific impact provides a global and integrated vision of the countries' research in this area.

\section{Materials and methods}

The articles used for analysis were obtained from the Science Citation Index Expanded (SCIE) 
database, which was accessed via the Web of Knowledge platform from terminals at the Pontificia Universidad Católica of Chile in Santiago. Only papers categorized as articles or reviews were considered; sources such as letters, editorial material, book reviews, proceedings, reprints, news and bibliographic articles were excluded.

To research publications in the field of "wine research", we used a strategy consisting of several components (Glanzel and Veugelers, 2006; Aleixandre et al., 2012): a) searches by specific words, b) searches by institutional addresses, c) searches in specific viticulture and enology journals, d) searches involving Latin-American countries, e) searches limited to a 5-year period.

a) For the searches involving specific words, we used the following terms:

$\mathrm{TS}=($ grapevin* or wines or "wine grap*" or "wine pro*" or "red wine*" or "white wine*" or winemaking or enolog* or viticult* or oenolog* or "wine cell*" or "wine yeast*" or winery or wineries). TS is the label for the field "topic", and records are retrieved if the above terms are included in the titles, keywords or abstracts of articles. Some roots were cut with an asterisk to obtain all of the documents associated with the derived words (e.g., by searching for enolog*, the SCIE database finds enology, enologist, enological, etc.).

b) For the searches for institutional addresses, we used the following terms:

$\mathrm{AD}=($ enolog* or viticult* or oenol*), where $\mathrm{AD}$ is the label for the institutional addresses of the authors.

c) For the searches in specific viticulture and enology journals, we used:

$\mathrm{SO}=$ American Journal of Enology and Viticulture or Australian Journal of Grape and Wine
Research or Ciencia e Técnica Vitivinícola or Journal International des Sciences de la Vigne et du Vin or South African Journal of Enology and Viticulture or VITIS. SO is the label for the name of the journal.

d) For the search limited to articles that were authored in Latin-American countries, we used the following:

$\mathrm{CY}=$ Argentina or Bolivia or Brazil or Chile or Colombia or Costa Rica or Cuba or Ecuador or El Salvador or Guatemala or Haiti or Honduras or Mexico or Nicaragua or Panama or Paraguay or Peru or Dominican Republic or Uruguay or Venezuela. CY is the label of the countries of the authors' institutions.

e) Finally, the analysis was limited to a 5-year period, 2006 to 2010.

The searches using specific words, institutions and journals $(a, b, c)$ were combined with the logical operator "or". These results were combined with countries (d) and time period (e) using the "and" operator.

The records obtained were exported to a relational database in Microsoft Access. The different variants of the same author or institution were unified because this information is not always standardized in SCIE. The information was analyzed to obtain bibliometric indicators of scientific productivity, patterns of collaboration, number of citations and impact. Data about the scientific productivity of the journals, institutions and countries were weighted based on whether English was the language of publication. A social network analysis was also carried out to identify the number of co-authorships, i.e., all combinations of pairs of authors or institutions on each paper, a process that is essential to identify research groups. The software Pajek (Batagelj and Mrvar, 2001) was used to construct and graphically represent the research groups and to visualize the networks. 
Table 1. Annual distribution of journals by publication language, 2010 impact factor and country.

\begin{tabular}{|c|c|c|c|c|c|c|c|c|c|c|}
\hline \multirow[b]{2}{*}{ Journal } & \multirow[b]{2}{*}{2006} & \multirow[b]{2}{*}{2007} & \multirow[b]{2}{*}{2008} & \multirow[b]{2}{*}{2009} & \multirow[b]{2}{*}{2010} & \multicolumn{3}{|c|}{ Total } & \multirow[b]{2}{*}{$\begin{array}{l}\text { Impact } \\
\text { Factor }\end{array}$} & \multirow[b]{2}{*}{ Country } \\
\hline & & & & & & $\begin{array}{c}\text { Total all } \\
\text { languages }\end{array}$ & $\begin{array}{l}\text { Only in } \\
\text { English }\end{array}$ & $\begin{array}{c}\% \text { in } \\
\text { English }\end{array}$ & & \\
\hline Revista Brasileira de Fruticultura & & 9 & 14 & 12 & 19 & 54 & 3 & 5.56 & 0.440 & Brazil \\
\hline Journal of Agricultural and Food Chemistry & 8 & 8 & 8 & 3 & 5 & 32 & 32 & 100 & 2.816 & USA \\
\hline Food Chemistry & 2 & 2 & 6 & 7 & 6 & 23 & 23 & 100 & 3.458 & United Kingdom \\
\hline Ciencia e Tecnologia de Alimentos & & 7 & 4 & 3 & 6 & 20 & 3 & 15 & 0.266 & Brazil \\
\hline Ciencia Rural & & & 3 & 6 & 8 & 17 & 1 & 5.88 & 0.343 & Brazil \\
\hline Quimica Nova & 2 & 4 & 5 & 1 & 3 & 15 & 0 & 0 & 0.744 & Brazil \\
\hline American Journal of Enology and Viticulture & 4 & 5 & 2 & 2 & 1 & 14 & 14 & 100 & 1.667 & USA \\
\hline International Journal of Food Microbiology & 1 & 5 & 2 & 3 & 3 & 14 & 14 & 100 & 3.143 & Netherlands \\
\hline Analytica Chimica Acta & 2 & 4 & 4 & & 3 & 13 & 13 & 100 & 4.311 & Netherlands \\
\hline Pesquisa Agropecuaria Brasileira & 2 & 1 & 3 & 6 & 1 & 13 & 2 & 15.38 & 0.687 & Brazil \\
\hline Ciencia e Agrotecnologia & & 3 & 6 & 3 & 1 & 13 & 2 & 15.38 & 0.567 & Brazil \\
\hline Talanta & & & 5 & 2 & 5 & 12 & 12 & 100 & 3.722 & United Kingdom \\
\hline Revista de la Facultad de Ciencias Agrarias & & 2 & 5 & 5 & & 12 & 1 & 8.33 & 0.020 & Argentina \\
\hline Scientia Agricola & 1 & 1 & 3 & 2 & 4 & 11 & 11 & 100 & 0.816 & Brazil \\
\hline Food Control & & 4 & 2 & 3 & 1 & 10 & 10 & 100 & 2.812 & United Kingdom \\
\hline $\begin{array}{l}\text { Journal of Industrial Microbiology \& } \\
\text { Biotechnology }\end{array}$ & 1 & 2 & 3 & 4 & & 10 & 10 & 100 & 2.416 & Germany \\
\hline Semina-Ciencias Agrarias & & 1 & 3 & 2 & 4 & 10 & 10 & 100 & 0.185 & Brazil \\
\hline Journal of Chromatography A & 2 & 3 & 3 & & 1 & 9 & 9 & 100 & 4.194 & Netherlnads \\
\hline World Journal of Microbiology \& Biotechnology & 2 & 2 & 2 & 1 & 2 & 9 & 9 & 100 & 1.214 & Netherlands \\
\hline $\begin{array}{l}\text { Journal International des Sciences de la Vigne } \\
\text { et du Vin }\end{array}$ & 1 & 1 & 3 & 2 & 2 & 9 & 8 & 88.89 & 0.913 & France \\
\hline Plant Disease & & 1 & 2 & 5 & & 8 & 8 & 100 & 2.387 & USA \\
\hline Ciencia e Investigacion Agraria & & 1 & 2 & 2 & 3 & 8 & 5 & 62.50 & 0.528 & Chile \\
\hline $\begin{array}{l}\text { International Journal of Food Science and } \\
\text { Technology }\end{array}$ & & 1 & 1 & 1 & 5 & 8 & 8 & 100 & 1.223 & United Kingdom \\
\hline Brazilian Archives of Biology and Technology & 2 & 2 & 1 & 3 & & 8 & 8 & 100 & 0.397 & Brazil \\
\hline Ciencia e Tecnica Vitivinicola & & & 2 & 3 & 2 & 7 & 1 & 14.29 & 0.636 & Portugal \\
\hline Current Microbiology & 3 & 1 & 1 & & 2 & 7 & 7 & 100 & 1.510 & USA \\
\hline Chilean Journal Of ogricultural Research & & & 1 & 4 & 2 & 7 & 7 & 100 & 0.385 & Chile \\
\hline Journal of Applied Microbiology & & 4 & 1 & & 2 & 7 & 7 & 100 & 2.365 & United Kingdom \\
\hline Tropical Plant Pathology & & & 2 & 3 & 2 & 7 & 5 & 71.43 & 0.448 & Brazil \\
\hline Vitis & & 1 & 2 & 2 & 1 & 6 & 6 & 100 & 0.662 & Germany \\
\hline Journal of The Brazilian Chemical Society & & & 1 & 2 & 3 & 6 & 6 & 100 & 1.343 & Brazil \\
\hline Letters in Applied Microbiology & & & 1 & 1 & 4 & 6 & 6 & 100 & 1.647 & United Kingdom \\
\hline Agricultura Tecnica & & 3 & 3 & & & 6 & 5 & 83.33 & 0,451 & Chile \\
\hline Journal of Sensory Studies & 2 & 1 & 1 & & 2 & 6 & 6 & 100 & 1.750 & USA \\
\hline Food Research International & 1 & & & 1 & 4 & 6 & 6 & 100 & 2.416 & USA \\
\hline Electroanalysis & 1 & & 2 & 1 & 2 & 6 & 6 & 100 & 2.721 & Germany \\
\hline European Food Research and Technology & & 1 & 1 & 3 & 1 & 6 & 6 & 100 & 1.585 & Germany \\
\hline Journal of the Science of Food And Agriculture & 1 & & & 1 & 3 & 5 & 5 & 100 & 1.360 & United Kingdom \\
\hline $\begin{array}{l}\text { Lebensmittel-Wissenschaft und-Technologie- } \\
\text { Food Science and Technology }\end{array}$ & 1 & & & 2 & 2 & 5 & 5 & 100 & 2.292 & United Kingdom \\
\hline Journal of Food Engineering & 1 & 1 & 1 & & 2 & 5 & 5 & 100 & 2.168 & United Kingdom \\
\hline Food Microbiology & & 1 & 3 & 1 & & 5 & 5 & 100 & 3.320 & United Kingdom \\
\hline Journal of Food Composition and Analysis & & & 3 & & 2 & 5 & 5 & 100 & 1.948 & USA \\
\hline Food Quality and Preference & & & & 1 & 4 & 5 & 5 & 100 & 3.013 & United Kingdom \\
\hline Spanish Journal of Agricultural Research & 1 & 2 & & 1 & 1 & 5 & 5 & 100 & 0.646 & Spain \\
\hline 7 journals with 4 articles & 5 & 7 & 8 & 5 & 3 & 28 & 26 & 92.86 & & \\
\hline 31 Journals with 3 articles & 10 & 14 & 19 & 31 & 19 & 93 & 80 & 86.02 & & \\
\hline 44 journals with 2 articles & 7 & 22 & 15 & 19 & 25 & 88 & 83 & 94.32 & & \\
\hline 238 journals with 1 article & 30 & 47 & 40 & 47 & 74 & 238 & 219 & 92.02 & & \\
\hline Total & 93 & 174 & 199 & 206 & 245 & 917 & 733 & 79.93 & & \\
\hline
\end{tabular}




\section{Results}

\section{Scientific productivity}

During the period analyzed, 917 research articles were published, and the number grew slightly from 93 in 2006 (10.1\%) to 245 (26.7\%) in 2010. The average number of articles per year was 183.4 (Table 1). The articles were published in 364 different journals of which 44 published 5 or more papers. Revista Brasileira de Fruticultura was the journal that published the greatest number of articles ( $\mathrm{n}=54$; Brazil) followed by the Journal of Agricultural and Food Chemistry ( $n=32$; USA), Food Chemistry ( $n=23$; United Kingdom) and Ciencia e Tecnologia de Alimentos ( $\mathrm{n}=20$; Brazil). Another 40 journals account for more than 4 papers each (Table 1). The specific viticulture and enology journals that published a large number of articles were the American Journal of Enology and Viticulture $(\mathrm{n}=14$; USA), Journal International des Sciences de la Vigne et du Vin (n=9; France), Ciencia e Tecnica Vitivinicola ( $\mathrm{n}=7$; Portugal) and VITIS $(\mathrm{n}=6$; Germany). A quarter of these journals were published in Brazil $(\mathrm{n}=11)$, another quarter in the United Kingdom and 7 in the USA. Most of the articles were published in English ( $\mathrm{n}=719,78.4 \%)$ but also notably Portuguese $(\mathrm{n}=157,17.1 \%)$ and Spanish ( $\mathrm{n}=34,3.7 \%)$. However, of the 11 most productive journals published in Brazil, only 5 published more than $50 \%$ of their articles in English, while this was the percentage for all of the journals published in Chile $(\mathrm{n}=3)$.

The SCIE subject areas that comprised more than $10 \%$ of published articles were as follows: 267 articles (29.1\%) were classified in the area of Agriculture, 219 (23.9\%) in Food Science and Technology, 191 in Chemistry (20.8\%) and 98 (10.7\%) in Biotechnology and Applied Microbiology.

1,803 institutions were identified of which 27 published more than 15 articles (Table 2). Most of the institutions were located in Brazil, Argentina and Chile. The Universidade de São Paulo, Brazil, ranked highest in institutional productivity with 84 articles followed by the Consejo Nacional de Investigaciones Científicas y Técnicas (Argentina) $(\mathrm{n}=57)$, the Universidade Estadual de Campinas (Brazil) ( $\mathrm{n}=53)$, the Universidade Federal do Rio Grande do Sul (Brazil) $(n=52)$ and the Embrapa Uva \& Vinho (Brazil) ( $n=51)$. If English was the language of publication of the articles, the most productive Latin American institutions, with more than $95 \%$ of the published articles, were the Pontificia Universidad Católica de Chile, the Universidad de Concepción (Chile), the Universidad Nacional de Tucumán (Argentina), the Instituto de Investigaciones Agropecuarias (INIA, Brazil) and the Centro de Referencia para Lactobacilos (CERELA, Argentina).

Of the 30 different countries that contributed to the publication of papers (Table 3), 9 were Latin American, and 21 were non-Latin American collaborators. Brazil ranked first with respect to scientific productivity $(\mathrm{n}=439)$, followed by Chile $(n=179)$, Argentina $(n=144)$ and Mexico $(n=90)$. If only the percentage of articles published in English is considered, the ranking was headed by Chile (94.97\%) and followed by Mexico (94.44\%) and Uruguay $(n=93.75 \%)$. The USA $(n=83)$, Spain $(n=73)$ and France $(n=53)$ should be highlighted within the non-Latin American countries. The increase in the number of published papers was highest in Brazil, which rose from 39 papers in 2006 to 116 in 2010, but significant growth also occurred in Argentina (from 14 to 39) and Chile (from 17 to 53) during the same time period. Figure 1 shows the weight of English in the national production of scientific articles compared to production in all languages.

The relative scientific productivity by number of inhabitants and Gross Domestic Product (GDP) was significantly greater in Chile (10.27 articles per million inhabitants and 0.69 per thousand million GPD) and Uruguay (9.43 articles per million inhabitants and 0.67) per thousand million GPD) than in other countries. Taking wine production 
Table 2. Annual distribution of articles and citations from the main viticulture institutions according to publication language.

\begin{tabular}{|c|c|c|c|c|c|c|c|c|c|c|c|c|c|c|c|}
\hline \multirow[b]{2}{*}{ Institutions } & \multirow[b]{2}{*}{ Country } & \multicolumn{8}{|c|}{ Articles } & \multicolumn{5}{|c|}{ Citations } & \multirow[b]{2}{*}{$\begin{array}{c}\text { Citations/ } \\
\text { article }\end{array}$} \\
\hline & & 2006 & 2007 & 2008 & 2009 & 2010 & $\begin{array}{c}\text { Total all } \\
\text { languages }\end{array}$ & $\begin{array}{c}\text { Total } \\
\text { English }\end{array}$ & $\begin{array}{c}\% \\
\text { In English }\end{array}$ & 2007 & 2008 & 2009 & 2010 & Total & \\
\hline Universidade de São Paulo (USP) & Brazil & 14 & 12 & 14 & 17 & 27 & 84 & 70 & 83.33 & 79 & 52 & 98 & 59 & 419 & 4.99 \\
\hline $\begin{array}{l}\text { Consejo Nacional de Investigaciones } \\
\text { Científicas y Técnicas (CONICET) }\end{array}$ & Argentina & 2 & 9 & 12 & 12 & 22 & 57 & 53 & 92.98 & 82 & 74 & 35 & 65 & 272 & 4.77 \\
\hline $\begin{array}{l}\text { Universidade Estadual de Campinas } \\
\text { (UNICAMP) }\end{array}$ & Brazil & 6 & 20 & 11 & 7 & 9 & 53 & 45 & 84.91 & 206 & 77 & 58 & 9 & 425 & 8.02 \\
\hline $\begin{array}{l}\text { Universidade Federal do Rio Grande } \\
\text { do Sul (UFRGS) }\end{array}$ & Brazil & 1 & 8 & 12 & 15 & 16 & 52 & 28 & 53.85 & 89 & 98 & 27 & 16 & 231 & 4.44 \\
\hline Embrapa Uva \& Vinho & Brazil & 2 & 8 & 13 & 17 & 11 & 51 & 10 & 19.61 & 41 & 47 & 30 & 7 & 127 & 2.49 \\
\hline $\begin{array}{l}\text { Pontificia Universidad Católica } \\
\text { de Chile }\end{array}$ & Chile & 2 & 16 & 11 & 7 & 13 & 49 & 48 & 97.96 & 174 & 75 & 49 & 29 & 342 & 6.98 \\
\hline Universidad de Chile & Chile & 4 & 7 & 8 & 12 & 11 & 42 & 39 & 92.86 & 94 & 37 & 32 & 42 & 281 & 6.69 \\
\hline $\begin{array}{l}\text { Universidade Federal de Santa } \\
\text { Catarina (UFSC) }\end{array}$ & Brazil & 1 & 7 & 15 & 5 & 7 & 35 & 22 & 62.86 & 88 & 90 & 12 & 10 & 213 & 6.08 \\
\hline $\begin{array}{l}\text { Institut National de la Recherche } \\
\text { Agronomique (INRA) }\end{array}$ & Francia & 2 & 5 & 11 & 5 & 7 & 30 & 29 & 96.67 & 49 & 53 & 24 & 19 & 213 & 7.1 \\
\hline Universidad Nacional de Cuyo & Argentina & 2 & 3 & 10 & 8 & 7 & 30 & 17 & 56.67 & 20 & 16 & 12 & 15 & 81 & 2.7 \\
\hline $\begin{array}{l}\text { Empresa Brasileira de Pesquisa } \\
\text { Agropecuária (EMBRAPA) }\end{array}$ & Brazil & 2 & 7 & 6 & 9 & 4 & 28 & 19 & 67.86 & 20 & 12 & 18 & 6 & 67 & 2.39 \\
\hline $\begin{array}{l}\text { Instituto Nacional de Tecnología } \\
\text { Agropecuaria (INTA) }\end{array}$ & Argentina & 1 & 4 & 4 & 9 & 10 & 28 & 26 & 92.86 & 58 & 15 & 17 & 17 & 109 & 3.89 \\
\hline $\begin{array}{l}\text { Universidade Federal de Lavras } \\
\text { (UFLA) }\end{array}$ & Uruguay & - & 2 & 9 & 9 & 8 & 28 & 11 & 39.29 & 11 & 14 & 24 & 21 & 70 & 2.5 \\
\hline $\begin{array}{l}\text { Universidad de la República } \\
\text { (UDELAR) }\end{array}$ & Chile & 7 & 3 & 4 & 4 & 9 & 27 & 25 & 92.59 & 198 & 45 & 27 & 16 & 339 & 12.55 \\
\hline $\begin{array}{l}\text { Universidad de Santiago de Chile } \\
\text { (USACH) }\end{array}$ & Chile & 2 & 1 & 8 & 8 & 8 & 27 & 24 & 88.89 & 14 & 13 & 45 & 13 & 88 & 3.26 \\
\hline University of California, Davis & $\begin{array}{l}\text { United } \\
\text { States }\end{array}$ & 8 & 4 & 5 & 7 & 3 & 27 & 25 & 92.59 & 64 & 79 & 41 & 28 & 456 & 16.89 \\
\hline Universidad de Talca & Chile & 5 & 4 & 4 & 3 & 9 & 25 & 23 & 92 & 3 & 39 & 8 & 10 & 154 & 6.16 \\
\hline $\begin{array}{l}\text { Universidade Estadual Paulista Júlio } \\
\text { de Mesquita Filho (UNESP) }\end{array}$ & Brazil & 4 & 5 & 5 & 6 & 5 & 25 & 19 & 76 & 36 & 7 & 18 & 8 & 84 & 3.36 \\
\hline Universidad de Concepción & Chile & 1 & 1 & 3 & 8 & 6 & 19 & 19 & 100 & 13 & 26 & 20 & 9 & 73 & 3.8 \\
\hline $\begin{array}{l}\text { Universidad Nacional de Tucumán } \\
\text { (UNT) }\end{array}$ & Argentina & 1 & 6 & 6 & 2 & 4 & 19 & 19 & 100 & 85 & 22 & 9 & 7 & 125 & 6.58 \\
\hline $\begin{array}{l}\text { Instituto de Investigaciones } \\
\text { Agropecuarias (INIA) }\end{array}$ & Brazil & 1 & 4 & 4 & 3 & 6 & 18 & 18 & 100 & 32 & 5 & 9 & 8 & 78 & 4.33 \\
\hline $\begin{array}{l}\text { Universidade Federal de Minas } \\
\text { Gerais (UFMG) }\end{array}$ & Brazil & - & 7 & 4 & 3 & 4 & 18 & 15 & 83.33 & 78 & 16 & 8 & 4 & 106 & 5.89 \\
\hline Universidade Federal da Bahia & Brazil & 2 & 5 & 3 & 3 & 4 & 17 & 14 & 82.35 & 21 & 29 & 6 & 4 & 84 & 4.94 \\
\hline $\begin{array}{l}\text { Empresa de Pesquisa Agropecuária } \\
\text { de Minas Gerais (EPAMIG) }\end{array}$ & Brazil & - & 1 & 4 & 6 & 5 & 16 & 2 & 12.50 & 3 & 7 & 5 & 1 & 16 & 1 \\
\hline $\begin{array}{l}\text { Instituto Agronômico de Campinas } \\
\text { (IAC) }\end{array}$ & Brazil & - & 5 & 6 & 3 & 2 & 16 & 7 & 43.75 & 17 & 10 & 4 & - & 31 & 1.94 \\
\hline $\begin{array}{l}\text { Universidade Federal de Santa Maria } \\
\text { (UFSM) }\end{array}$ & Brazil & 2 & 6 & 4 & 3 & 1 & 16 & 4 & 25 & 24 & 5 & 7 & - & 69 & 4.13 \\
\hline $\begin{array}{l}\text { Centro de Referencia para } \\
\text { Lactobacilos (CERELA) }\end{array}$ & Argentina & - & 6 & 5 & 1 & 3 & 15 & 15 & 100 & 85 & 13 & 6 & 6 & 110 & 7.33 \\
\hline Universidad de Buenos Aires & Argentina & 4 & 2 & 1 & 4 & 4 & 15 & 13 & 86.67 & 61 & 9 & 20 & 10 & 221 & 14.73 \\
\hline Universidad Nacional del Comahue & Argentina & 2 & 6 & 1 & 2 & 4 & 15 & 15 & 100 & 41 & 6 & 6 & 6 & 75 & 5 \\
\hline
\end{tabular}


Table 3. Annual production of articles by country according to publication language and number of citations.

\begin{tabular}{|c|c|c|c|c|c|c|c|c|c|c|c|c|c|c|}
\hline \multirow[b]{2}{*}{ Country } & \multicolumn{8}{|c|}{ Articles } & \multicolumn{6}{|c|}{ Citations } \\
\hline & 2006 & 2007 & 2008 & 2009 & 2010 & $\begin{array}{c}\text { Total all } \\
\text { languages }\end{array}$ & $\begin{array}{l}\text { Only in } \\
\text { English }\end{array}$ & $\begin{array}{l}\% \text { In } \\
\text { English }\end{array}$ & 2006 & 2007 & 2008 & 2009 & 2010 & Total \\
\hline Brazil & 39 & 86 & 101 & 97 & 116 & 439 & 276 & 62.87 & 330 & 676 & 442 & 316 & 131 & 1,895 \\
\hline Chile & 17 & 34 & 38 & 37 & 53 & 179 & 170 & 94.97 & 221 & 327 & 202 & 125 & 111 & 986 \\
\hline Argentina & 14 & 26 & 26 & 39 & 39 & 144 & 126 & 87.50 & 226 & 294 & 147 & 131 & 86 & 884 \\
\hline Mexico & 13 & 16 & 21 & 23 & 17 & 90 & 85 & 94.44 & 137 & 71 & 134 & 160 & 35 & 537 \\
\hline United States & 15 & 16 & 17 & 21 & 14 & 83 & 81 & 97.59 & 287 & 224 & 161 & 96 & 57 & 825 \\
\hline Spain & 5 & 18 & 8 & 10 & 32 & 73 & 68 & 93.15 & 64 & 262 & 40 & 62 & 68 & 496 \\
\hline France & 5 & 6 & 16 & 13 & 13 & 53 & 51 & 96.23 & 75 & 75 & 85 & 109 & 38 & 382 \\
\hline Uruguay & 8 & 3 & 6 & 4 & 11 & 32 & 30 & 93.75 & 55 & 198 & 51 & 27 & 17 & 348 \\
\hline Italy & 3 & 11 & 2 & 10 & 3 & 29 & 27 & 93.10 & 6 & 154 & 6 & 47 & 8 & 221 \\
\hline Colombia & & 2 & 2 & 5 & 9 & 18 & 14 & 77.78 & & 13 & 6 & 29 & 15 & 63 \\
\hline Australia & 1 & 1 & 3 & 4 & 4 & 13 & 13 & 100 & 30 & 22 & 48 & 38 & 16 & 154 \\
\hline Portugal & 2 & & 2 & 3 & 6 & 13 & 13 & 100 & 16 & & 10 & 35 & 29 & 90 \\
\hline Germany & 1 & & 2 & 2 & 6 & 11 & 11 & 100 & 3 & & 17 & 15 & 23 & 58 \\
\hline Venezuela & 1 & 2 & 2 & 3 & 3 & 11 & 10 & 90.91 & 30 & 5 & 4 & 0 & 4 & 43 \\
\hline Netherlands & 1 & 1 & 1 & 2 & 4 & 9 & 9 & 100 & 6 & 2 & 2 & 11 & 14 & 35 \\
\hline Canada & 1 & & 2 & 2 & 2 & 7 & 7 & 100 & 3 & & 18 & 21 & 8 & 50 \\
\hline Costa Rica & & 2 & 1 & 2 & 2 & 7 & 7 & 100 & & 13 & 0 & 21 & 1 & 35 \\
\hline Peru & & 3 & 2 & 1 & 1 & 7 & 6 & 85.71 & & 69 & 8 & 17 & 0 & 94 \\
\hline $\begin{array}{l}\text { United } \\
\text { Kingdom }\end{array}$ & & 2 & 2 & 1 & 2 & 7 & 7 & 100 & & 74 & 37 & 13 & 6 & 130 \\
\hline India & & 2 & 1 & 1 & 2 & 6 & 6 & 100 & & 0 & 12 & 13 & 13 & 38 \\
\hline China & & 3 & & 2 & 1 & 6 & 6 & 100 & & 2 & & 21 & 5 & 28 \\
\hline Cuba & 1 & & & 1 & 2 & 4 & 4 & 100 & 0 & & & 17 & 4 & 21 \\
\hline Russia & & 2 & & 2 & & 4 & 4 & 100 & & 0 & & 19 & & 19 \\
\hline Sweden & & 2 & 1 & 1 & & 4 & 4 & 100 & & 97 & 9 & 13 & & 119 \\
\hline
\end{tabular}
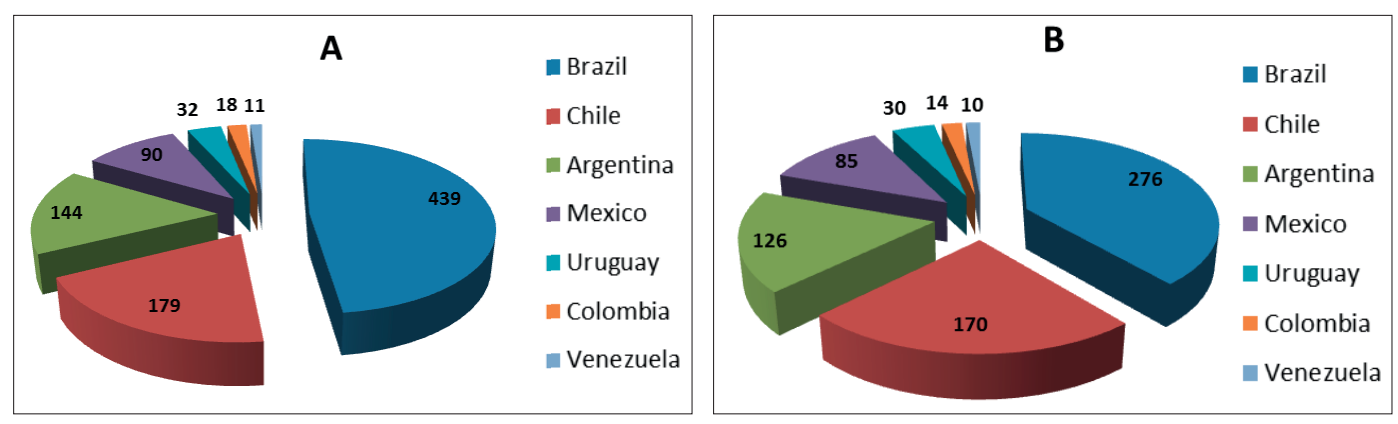

Figure 1. Distribution of articles in English and all other languages in Latin American countries. A: articles in all languages. B: articles in English 
into account, Argentina and Chile are the major wine producers of Latin America, accounting for $92.3 \%$ of production, outweighing the wine sectors from other producing countries (Table 4).

\section{Patterns of collaboration}

Most of the published articles were the result of a national collaboration $(\mathrm{n}=415,45.2 \%)$, i.e., two or more institutions in the same country participated. In 281 articles, we identified the participation of a foreign institution (30.6\%), and 328 papers were authored by a single national institution (35.8\%). The number of national and international collaborations increased over time, but the number of papers published by a single institution remained virtually stable (Figure 2).

The social network analysis resulted in the identification of a total of 8 institutional collaborative groups of which the largest was made up of 61 linked institutions (Figure 3). The numbers on the lines that link the institutions indicate the number of articles published in collaboration.

In the largest group, two institutions occupy a central position. On one side of the network, the Universidade de São Paulo (Brazil) established collaborations, with 7 papers each, with 12 institutions including the Universidade Estadual Paulista Júlio de Mesquita Filho, the Universidade

Table 4. Scientific productivity by country according to GPD, number of inhabitants and percentage of wine production.

\begin{tabular}{|c|c|c|c|c|c|c|}
\hline Country & $\begin{array}{l}\text { Number of } \\
\text { Inhabitants } \\
2010 \text { (A) in } \\
\text { millions }\end{array}$ & $\begin{array}{l}\text { Number of } \\
\text { articles (B) }\end{array}$ & $\begin{array}{c}\mathrm{B} / \mathrm{A} \\
\text { (articles } \\
\text { by million } \\
\text { inhabitants) }\end{array}$ & $\begin{array}{c}\text { GDP (PPP) } \\
2010 \text { in millions } \\
\text { of dollars USA } \\
\text { (C) }\end{array}$ & $\begin{array}{c}\mathrm{B} / \mathrm{C} \\
\text { (articles by } \\
\text { thousand } \\
\text { million GPD) }\end{array}$ & $\begin{array}{c}\text { Wine } \\
\text { production } \\
(\%)\end{array}$ \\
\hline Argentina & 41.12 & 144 & 3.5 & 642.402 & 0.22 & 50.39 \\
\hline Brazil & 198.36 & 439 & 2.21 & 2.172 .058 & 0.20 & 1.13 \\
\hline Chile & 17.43 & 179 & 10.27 & 257.884 & 0.69 & 41.91 \\
\hline Colombia & 47.55 & 18 & 0.38 & 435.367 & 0.04 & - \\
\hline Mexico & 116.15 & 90 & 0,77 & 1.629 .184 & 0.05 & 3.9 \\
\hline Uruguay & 3.39 & 32 & 9.43 & 47.986 & 0.67 & 3.75 \\
\hline Venezuela & 29.89 & 11 & 0.36 & 345.210 & 0.03 & - \\
\hline
\end{tabular}

Source: Organisation Internationale de la Vigne et du Vin.

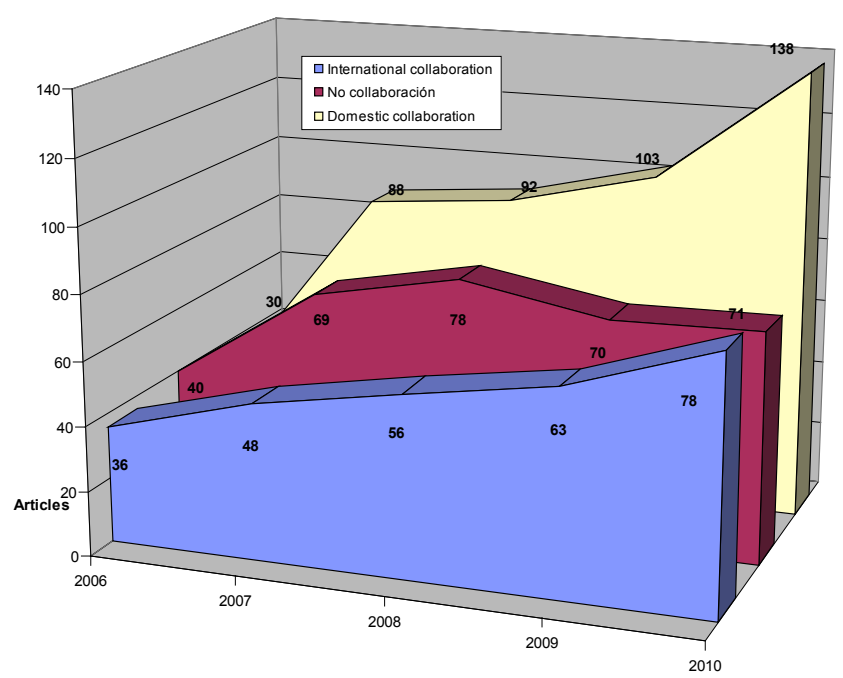

Figure 2. Annual distribution of domestic versus international collaborations. 
Federal de Lavras and Universidade Estadual de Campinas. On the other side, the Consejo Nacional de Investigaciones Científicas y Técnicas (Argentina) collaborated widely with the Universidad Nacional de Comahue $(\mathrm{n}=12)$ and the Instituto de Agroquímica y Tecnología de Alimentos from Consejo Superior de Investigaciones Científicas (Spain, $\mathrm{n}=9$ ). Other important collaborations were established between the Argentinian Universidad Nacional de Tucaman and the Centro de Referencia para Lactobacilos ( $\mathrm{n}=14)$, the Brazilian Embrapa Uva \& Vinho and the Universidade Federal do Rio Grande do Sul ( $\mathrm{n}=17$ ), and the Universidade Federal de Lavras and the Empresa de Pesquisa Agropecuaria de Minas Geraias ( $n=13)$. Figure 4 shows the groups with smaller numbers of components. The group with 7 components had the Universidad de Santiago de Chile as its central institution, which established collaborations with several centers from Chile, Spain (subsidiaries of the Spanish Research Council-CSIC) and the Australian Wine Research Institute.
Figure 4 shows the network of collaborations between countries and their intensity. The degree of cooperation is highest between Chile and Spain $(n=20)$ followed by Argentina and Spain ( $\mathrm{n}=19)$, Brazil and the USA $(n=19)$ and Mexico and the USA $(n=19)$.

\section{Citations and impact}

The most productive journals with the greatest impact factors (IFs from 2010) were Analytica Chimica Acta ( $\mathrm{IF}=4.311)$ and the Journal of Chromatography A (IF=4.194). Four other journals had IFs greater than 3 points: Food Chemistry, Talanta, Food Microbiology, International Journal of Food Microbiology and Food Quality and Preference (Table 1). The journals with the highest IFs are usually published in the United Kingdom, the Netherlands and the USA.

The most cited Latin American institution was the Universidade Estadual de Campinas ( $\mathrm{n}=425$ cita-

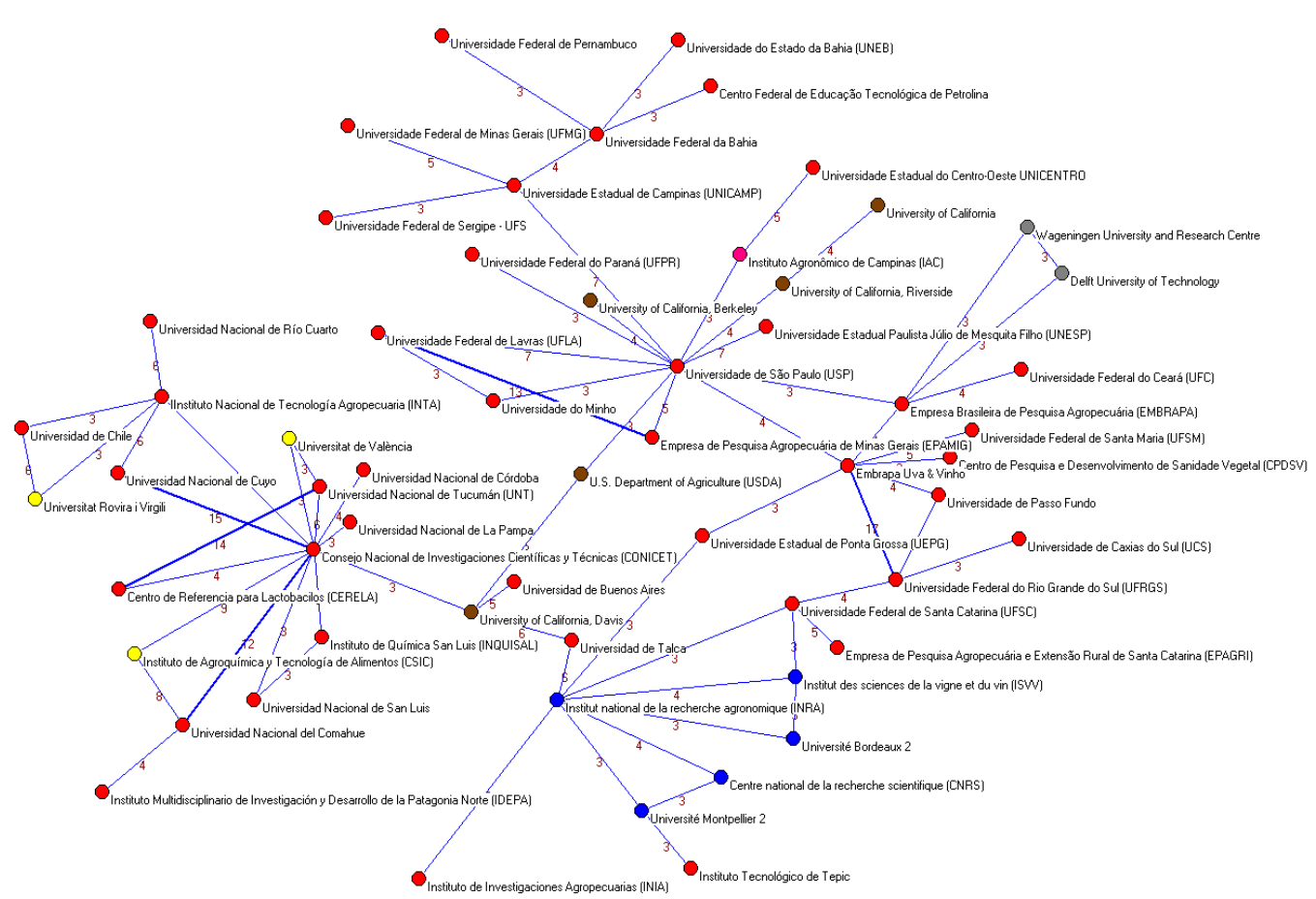

Figure 3. Main institutional network by region. Color of institutions: Red, Latin American; Yellow, Spanish; Blue, French; Grey, Netherlands; Brown, USA. 
tions) followed by the Universidade de São Paulo $(\mathrm{n}=419)$, the Pontificia Universidad Católica de Chile $(n=342)$ and the Universidad de Chile $(n=339)$ (Table 2). The Universidad de Buenos Aires (Argentina) had the highest number of citations per paper with an average of 14.73 followed by the Universidad de Chile ( $\mathrm{n}=12.55)$ and the Universidade Estadual de Campinas (Brazil) $(\mathrm{n}=8.02)$.

The countries with the highest total citations were Brazil ( $\mathrm{n}=1895)$, Chile $(\mathrm{n}=986)$ and Argentina $(n=884)$. However, the number of citations per article was higher in Peru ( $\mathrm{n}=13.43$ citations per paper) and Uruguay $(\mathrm{n}=10.87)$ (Table 3$)$.

\section{Discussion}

The economic, political and social context of Latin America has delayed scientific and technological development. However, beginning in the 1990s, new policies for funding research were implemented that are now paying off (Albornoz, 2001), and the Latin American scientific community is gaining significance in many areas. The number of papers published in international journals by Latin American authors included in the SCIE doubled during the period from 19972007 (Babini, 2011). This is consistent with data from our work that shows remarkable growth in the publication of scientific research papers over the five years analyzed (from 10 to 26.7\%). This growth has been observed in other areas of research, such as ceramics (Rojas-Sola et al., 2009), psychology (Sanchez Sosa, 2008; VeraVillarroel et al., 2011) and health technology (Pichon-Riviere, 2009).

Other reasons for this growth could be the increasing number of Latin American journals included in the SCIE, which has grown from 48 journals in 2006 to 179 in 2010. For most countries, such as Argentina, Chile, Mexico and Venezuela, the number of included journals has been multiplied by 3 . However, the growth was most evident in Brazil where the number of journals increased by a factor of 4, from 21 in 2006 to 89 in 2010 . However, coverage of Latin American journals in international bibliographic databases (the SCIE in particular) remains low. Consequently, high quality papers originating in Latin American countries are usually published in the USA or in European

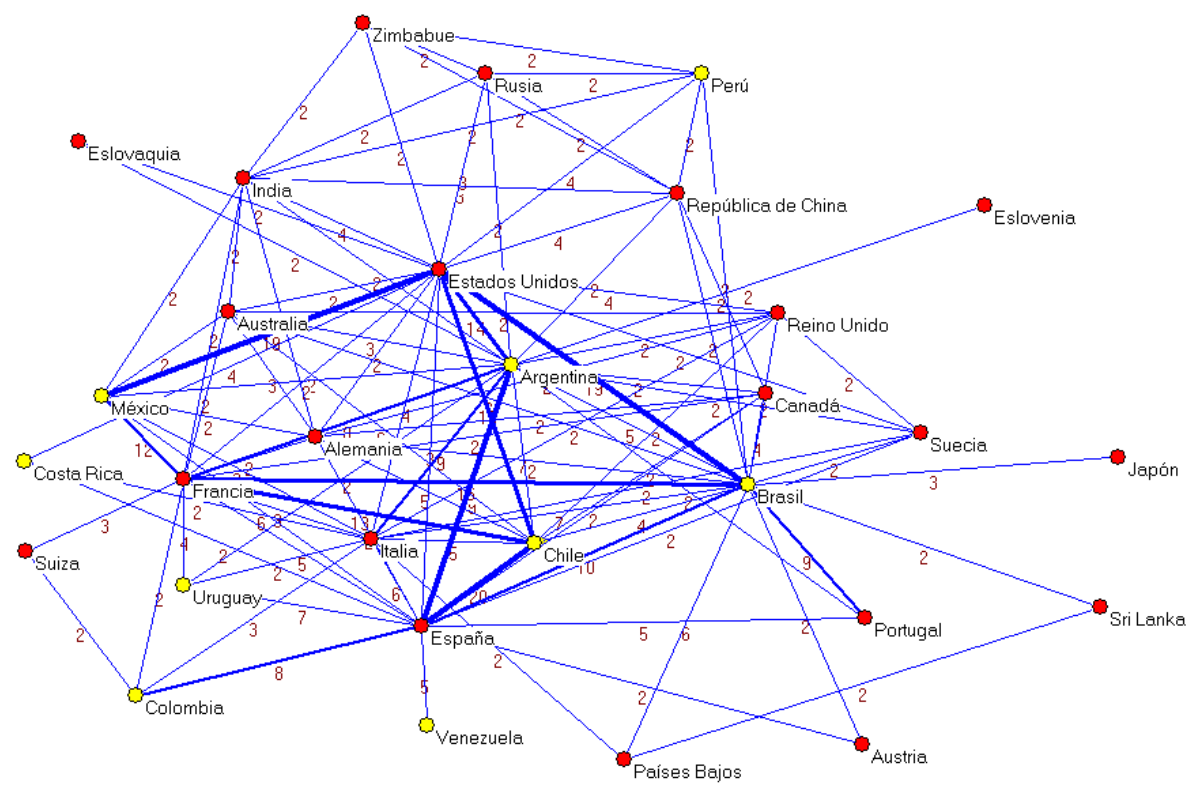

Figure 4. Network of collaborations between countries. 
journals. These journals hold a privileged position in the scientific mainstream, so they are able to attract papers from leading scientists.

If research is to progress, collaboration between institutions from different countries is necessary (Cunningham and Dilon, 1997; Katz and Martin, 1997; Newman, 2004). Differences in the level of scientific and technological cooperation between nations has been reported in various international forums in which appeals are also made to encourage international collaboration (Albornoz, 2001; Gonzalez-Alcaide et al., 2008). Stimulating the formation of groups and networks that bring together scientists, technologists and other stakeholders from different countries and promote the joint use of their knowledge is a central aspect of strategies for cooperation (Valderrama Zurián et al., 2008) because these groups advance knowledge, improve quality, and increase innovation and competitiveness (Cunningham and Dillon, 1997).

The papers we studied were published not only in viticulture and enology journals but in numerous journals from other subject areas such as food science and technology, food chemistry, microbiology, plant diseases, etc., as well as general agricultural research journals. This diversity is logical due to the multidisciplinary nature of the study area and the existence of extensive collaborations and synergies between viticulture and enology and other disciplines (Glanzel and Veugelers, 2006; Aleixandre-Benavent et al., 2012). This diversity in subject areas should instruct researchers seeking information on viticulture and enology to expand their search to related or general knowledge journals such as those identified in this study.

Brazil stands out as a country with the greatest scientific productivity and absolute number of citations in Latin America. Brazil's leadership can be explained by the fact that research spending and development in the country represents $60 \%$ of the investment in the entire region (Babini,
2011), by the magnitude of other indicators such as population size, which is 5 times the number of inhabitants in Argentina and more than 10 times the number in Chile, the other two large Latin American wine producers, or by the number of journals included in the SCIE ( 89 in 2010 versus 21 in Chile and 14 in Argentina). For these reasons, Brazilian institutions have often had greater absolute scientific productivity and impact in terms of the number of citations. However, the relative productivity measure of citations per paper shows that institutions in the other two countries compete with those in Brazil. However, when English language publications are taken into account, only a small percentage of the articles in the six most productive Latin American journals, all published in Brazil, are published in English. From this we can deduce that these are local journals, which despite being indexed in SCIE, likely do not have a high impact. This distortion not only affects the ranking of the most productive Latin American journals, but it also affects institutions; the Pontificia Universidad Católica de Chile leads in the ranking of Latin America's most productive institutions with a higher percentage of articles published in English and is ahead of other Brazilian institutions such as the Universidade de São Paulo, the Universidade Estadual de Campinas, the Universidade Federal do Rio Grande do Sul, and other Argentine institutions such as the Consejo Nacional de Investigaciones Científicas y Técnicas. Similarly, in the ranking of countries, Brazil is surpassed by Chile, Mexico, Uruguay and Argentina.

Social network analysis identified the most relevant research centers and universities that had scientific collaborations. These institutions could be considered to be on the "research front" in viticulture and enology in Latin America (Gonzalez-Alcaide et al., 2008). Increasing numbers of international collaborations observed throughout the study period are a positive sign indicating openness to foreign research from Latin American countries in this discipline. Additionally, collaboration with 
Latin American countries is particularly evident in countries among the scientific elite such as the United States, the European Union and Australia, and it occurs through several institutions in the USA (e.g., University of California in Davis, Berkeley and Riverside and the US Department of Agriculture), Spain (e.g., Spanish Research Council-CSIC through the Instituto de Agroquímica y Tecnología de Alimentos, the University of Valencia and the University Rovira Virgili) and France (e.g., the Institut National de la Recherche AgronomiqueINRA, the Institut des Sciences de la Vigne et du Vin, the University of Bordeaux and the University of Montpellier). Implicit in these collaborations is the establishment of agreements that allow for the exchange of researchers and students as well as many collaborative research projects. An example of this dynamic in the fields of viticulture and enology is the agreement between the European Union and the Pontificia Universidad Católica of Chile, Stellenbosch University of South Africa and the École d'Ingénieurs de Changins of Switzerland for the Erasmus Mundus Vintage International Masters of Science Programme (http://www.vintagemaster. com). Erasmus Mundus is a program that aims to improve the quality of European higher education and promote understanding between people and cultures through cooperation with developing countries. These agreements enable researchers, teachers and students from the European Union, Chile, Switzerland and South Africa to take part in scientific programs and, therefore, increase their mobility. The promotion of these academic and research opportunities in foreign centers is considered critical to the internationalization of science (Ponds, 2009).

Despite the growing degree of international collaboration between Latin American countries and those of the scientific elite (mainly the United States, European Union, Australia and Canada), intensive ongoing cooperation between Latin American countries is lacking. For example, Chile collaborated with Spain on 19 papers, with the USA on 15 and on 13 with France but on only 7 with its neighbor, Argentina. The same phenomenon can be observed with Brazil, a country that collaborated on 19 articles with the USA, 16 with France and 10 with Spain but only on 5 papers with neighboring Argentina. This preference for Latin American countries to establish their links with scientifically elite countries is possibly driven by their research policies (Glanzel and Veugelers, 2006).

Knowledge of research networks in a specific scientific field provides several advantages for academics and researchers. First, it provides them with trustworthy information about existing active research groups in the discipline and opens opportunities for increasing their circle of contacts, participating in discussion forums and exchanging ideas on relevant topics as well as integrating into any of the identified groups (González-Alcaide et al., 2008; Wagner and Leydesdorff, 2005). On the other hand, network analysis identifies the institutions that occupy more central places in the network, which can be helpful when deciding on the convenient research centers with which to establish collaborative arrangements or conduct multicentric studies. The centers of a collaboration network with many connections will be preferentially chosen by new research groups seeking to initiate a scientific collaboration, and a group rich in connections will increase their influence more rapidly (Barbasi, 1999). Other benefits arise from the fact that identifying groups with similar scientific interests prevents the duplication of experiments, which increases the effectiveness of research and the impact of citations (Figg et al., 2006; Teasley and Wolinsky, 2001).

As we have seen, Latin American authors should use domestic and international journals to disseminate their research. Domestic journals should have a moderate impact factor compared to journals from the USA, the United Kingdom and the Netherlands. The explanation for this phenomenon could be that journals from non-Latin American countries are usually published in English, the current international language of science, as opposed to Latin American journals that are published in Portuguese and Spanish. Logically, only a certain number of 
researchers can read and cite such articles. Several studies have analyzed the relationship between the language of publication and the number of citations and have demonstrated that works published in journals edited in English are cited more often (Gonzalez-Alcaide et al., 2012).

This paper has some limitations that should be discussed. First, the SCIE does not include all of the published scientific literature on viticulture and oenology, so other bibliographic databases and additional data gathering from Latin American science journals could have been used as an alternative or a supplement. However, we used the SCIE because it has the following advantages: a) The SCIE is widely used in studies analyzing activity in science and technology because it includes the highest impact journals, which helps focus analyses on the most relevant authors and research centers (Rivera et al., 2010; Llorente-Bousquets, 2010; Rojas-Sola et al., 2009); b) It provides the names of all of the authors on the papers and all their institutional affiliations, which allowed us to determine the indicators of cooperation between researchers and their institutions; c) It makes the number of citations that articles have received available, and an additional resource, the Journal Citation Reports, provides the impact factors of journals, information that does not exist in other databases. Second, this study did not allow us to investigate the contribution of Latin-American viticulture and enology research to the progress of scientific knowledge. However, this limitation can be seen as a fruitful avenue for future research. It should also be noted that the absence of an impact factor for some journals or papers does not mean a lack of quality or a lack of a role in the transmission of knowledge. Impact indicators provide, above all, a measure of the utility rather than quality of the publications.
Regardless of these limitations, this paper identified the journals, institutions and countries with the greatest productivity and impact in the field of Latin-American viticulture and enology in recent years, as well as the members of research groups with the greatest number of collaborations and who can be considered the leaders or the heads of research in the discipline.

In conclusion, this study provides an indication of the state of research in Latin America in the field of viticulture and enology based on the analysis of articles published in journals included in the SCIE. The results highlight the significant growth in the number of research papers published from 2006 to 2010, although this growth is due in part to the increase in the number of journals included in the SCIE, some of which are published in local, non-English journals. When the influence of being published in English is considered, significant differences were observed in the productivity rankings of journals, institutions and countries. There was an increasing trend in the degree of international collaboration in Latin America, mainly with nonAmerican viticulture and enology institutions and countries. Future work in this area could identify newly emerging groups and the evolution of already recognized groups over time.

\section{Acknowledgements}

The authors wish to thank the Departamento de Fruticultura y Enología of the Pontificia Universidad Católica of Chile for the use of their facilities and the development of this work. This work is part of the collaborative activities of the European Union Erasmus Mundus Program Action 3 for the exchange of professors and researchers among the members of the Vintage Master Consortium. 


\title{
Resumen
}

\begin{abstract}
J.L. Aleixandre, E. Bordeu, J.L. Aleixandre-Tudó, M. Bolaños y R. Aleixandre-Benavent. 2013. Productividad y colaboración científica en viticultura y enología en los países latinoamericanos. Cien. Inv. Agr. 40(2): 429-443. El objetivo de este trabajo fue analizar la actividad científica de los investigadores en los países latinoamericanos en viticultura y enología mediante análisis bibliométrico de los artículos incluidos en la base de datos Science Citation Index Expanded durante el período 2006 a 2010. Un total de 917 artículos de investigación fueron publicados en 364 revistas nacionales e internacionales. Destaca un crecimiento importante en los trabajos de investigación publicados en el período, sobre todo en Brasil, Argentina y Chile, así como una colaboración internacional cada vez mayor, sobre todo con los países productores de uva y vino no americanos. También se llevó a cabo un análisis de redes sociales de la colaboración entre instituciones y países. El análisis combinado de la productividad, la colaboración científica y el impacto ofrece una visión global e integrada de los países que investigan en esta área.
\end{abstract}

Palabras clave: factor de impacto, países de América Latina, análisis de redes, colaboración científica, productividad científica, viticultura y enología.

\section{References}

Albornoz, M. 2001. Política Científica y Tecnológica: Una visión desde América Latina. Revista Iberoamericana de Ciencia, Tecnología, Sociedad e Innovación. $\mathrm{N}^{\circ} 1$. Available online at: http://www.oei.es/revistactsi/numero1/albornoz. htm (Website accessed March 27, 2012).

Aleixandre, J.L. and F. Crespo. 2005. Geografía Vitivinícola Nacional e Internacional. Valencia: Editorial Intertécnica.

Aleixandre-Benavent, R., J.C. Valderrama Zurian, and G. Gonzalez Alcaide. 2007. The impact factor of scientific journals: Limitations and alternative indicators. El Profesional de la Información 16:4-11.

Aleixandre-Benavent, R., J.L. Aleixandre-Tudó, G., González Alcaide, A. Ferrer Sapena, J.L. Aleixandre, and W. du Toit. 2012. Bibliometric analysis of publications by South African viticulture and oenology research centres. South African Journal of Science, 108(5/6):74-84.

Babini, D. 2011. Acceso abierto a la producción científica de América Latina y el Caribe. Revista Iberoamericana de Ciencia, Tecnología y Sociedad 17(6):1-24.
Batagelj, V., and A. Mrvar. 2001. Pajek Program for Large Network Analysis. Slovenia: University of Ljubljana. Available online at: http://vlado.fmf. uni-lj.si/pub/networks/pajek/ (Website accessed January 7, 2013).

Cunningham, S.J., and S.M. Dillon. 1997. Authorship patterns in information systems. Scientometrics 39: 19-27.

Fanzone, M., A. Peña-Neira, M. Gil, V. Jofré, M. Assof, and F. Zamora. 2012. Impact of phenolic and polyssaccharide composition in commercial value of Argentineam Malbec and Cabernet Sauvignon wines. Food Research International 45:402-414.

Figg, W.D., L. Duna, and D.J. Liewehr. 2006. Scientific collaboration results in higher citation rates of published articles. Pharmacotherapy 26:759767.

Glänzel, W. and R. Veugelers. 2006. Science for wine: a bibliometric assessment for wine and grape research for wine-producing and consuming countries. American Journal of Enology and Viticulture 57:23-32.

González, G., A. Navarro, L. de Barbén, L. Albornoz, and A. Hidalgo. 2003. Caracterización química 
de efluentes de bodegas. Mendoza (Argentina). Rev. Fac. Cienc. Agrar., Univ. Nac. Cuyo 25:99105.

González-Alcaide, G., J.C. Valderrama-Zurián, and R. Aleixandre-Benavent. 2008a. Research fronts and collaboration patterns in Reproductive $\mathrm{Bi}$ ology. Coauthorship networks and institutional collaboration. Fertility and Sterility 90:941-56.

Gonzalez-Alcaide, G., A. Alonso Arroyo, J. Gonzalez De Dios, A. Perez Sempere, J.C. Valderrama Zurian, and R. Aleixandre-Benavent. 2008b. Coauthorship networks and institutional collaboration in Revista de Neurología. Revista de Neurologia 46:642-651.

González-Alcaide, G., J.C. Valderrama-Zurián, and R. Aleixandre-Benavent. 2012. The Impact Factor In Non-English-Speaking Countries. Scientometrics 90:1-15.

González-Neves, G., R. Gil, L. Barreiro, and G. Favre. 2010. Pigment profile of red wines CV. Taqnnat made with alternative winemaking techniques. Journal of Food Composition and Analysis 23:447-454.

Granato, D., F. Chizuko Uchida Katayama, and I. Alves de Castro 2011. Phenolic composition of South American red wines classified according to their antioxidante activity, retail price and sensory quality. Food Chemistry 129:366-373.

Katz, J.S. and B.R. Martin 1997. What is research collaboration? Research Policy 26:1-18.

Lucena, A.P.S., R.J.B. Nascimento, J.A.C. Maciel, J.X. Tavares, J.M. Barbosa-Filho, and E.J. Oliveira 2010. Antioxidant activity and phenolic content of selected Brazilian wines. Journal of Food Composition and Analysis 23:30-36.

Newman, M.E.J. 2004. Coauthorship networks and patterns of scientific collaboration. Proceedings of the National Academy of Science of the USA 101:5200-5205.

Oliver, P., R.A. Rodríguez, M.R. Castro, M. Echegaray, C.A. Palacios, H. Klaus, and S.M. Udaquiola. 2006. Análisis water pinch en la industria del vino. XXX Congreso Interamericano de Ing- eniería Sanitaria y Ambiental. 26-30 Noviembre 2006. Punta Este, Uruguay.

Organisation Internationale de la Vigne et du Vin. Available online at: http://www. www.oiv.int. (Website accessed April 28, 2013).

Pichon-Riviere, A., R.M. Ceballos, and E. Briones, E. 2009. Health technology assessment in Latinamerica and the Caribbean, facilitators and barriers for international collaboration: a survey. Value in Health 12:488.

Ponds, R. 2009. The limits to internationalization of scientific research collaboration. Journal of Technology Transfer. 34:76-94.

Rojas-Sola, J.I., and B. Jordá-Albiñana. 2009. Análisis bibliométrico de las publicaciones científicas españolas en la categoría materials science, ceramics de la base de datos JCR (SCI) (1997-2008). Boletín de la Sociedad Española de Cerámica y Vidrio 48:255-260.

Sanchez Sosa, J.J. 2008. Professional collaboration between psychologists and other health professionals in healthcare settings in Latin America. International Journal of Psychology 43:171.

Teasley, S. and S. Wolinsky 2001. Scientific collaborations at a distance. Science 292:2254-2255.

Valderrama Zurián, J.C., G. González Alcaide, F.J. Valderrama Zurián, R. Aleixandre-Benavent, and A. Miguel Dasit. 2007. Coauthorship Networks and Institutional Collaboration in Revista Española de Cardiología Publications. Revista Española de Cardiología 60:117-130.

Vera-Villarroel, P., W. López-López, S. Lillo, and L. Silva. 2011. La producción científica en psicología latinoamericana: Un análisis de la investigación por países. Revista Latinoamericana de Psicología 43:95-104.

Wagner, C.S. and L. Leydesdorff. 2005. Networks structure, self-organization, and the growth of international collaboration in science. Research Policy 34:1608-18.

White, H.D. and K. Mccain K. 1989 Bibliometrics. Annual Review of Information Science and Technology 24:119-186. 
